\title{
Oral Progestins in Hormonal Contraception: Importance and Future Perspectives of a New Progestin Only-Pill Containing 4 mg Drospirenone
}

\section{Orale Gestagene in der hormonellen Kontrazeption: Stellenwert und Zukunftsaussichten eines neuen Gestagen-Monopräparats mit 4 mg Drospirenon}

(c) (1) $\Theta$

Authors

Thomas Römer ${ }^{1}$, Johannes Bitzer ${ }^{2}$, Christian Egarter ${ }^{3}$, Peyman Hadji 4, 5 , Marion Kiechle ${ }^{6}$, Heike Kramer ${ }^{7}$,

Patricia G. Oppelt ${ }^{8}$, Klaus Peters ${ }^{9}$, Petra Stute ${ }^{10}$, Katrin Schaudig ${ }^{11}$, Inka Wiegratz ${ }^{12,13}$, Pedro-Antonio Regidor ${ }^{14}$

Affiliations

1 Abteilung für Gynäkologie und Geburtshilfe, Evangelisches

Klinikum Köln Weyertal GmbH, Köln, Germany

2 Klinik für Geburtshilfe und Gynäkologie, Universitäts-

krankenhaus Basel, Basel, Switzerland

3 Abteilung für Gynäkologische Endokrinologie, Medizinische Universität Wien, Wien, Austria

4 Frankfurter Hormon und Osteoporosezentrum, Frankfurt am Main, Germany

5 Philipps Universität Marburg, Marburg, Germany

6 Direktorin der Frauenklinik, Universitätsklinikum Rechts

der Isar der Technischen Universität München (TUM),

München, Germany

7 Ärztliche Gesellschaft zur Gesundheitsförderung e. V., Spardorf/Erlangen, Germany

8 Universitätsfrauenklinik Erlangen, Erlangen, Germany

9 Frauenarzt Praxis Hamburg, Hamburg, Germany

10 Klinik für Gynäkologie und Geburtshilfe, Universitäts-

klinikum Inselspital Bern, Bern, Switzerland

11 Praxis für gynäkologische Endokrinologie HORMONE HAMBURG, Hamburg, Germany

12 Kinderwunsch \& Hormonzentrum Frankfurt Am Palmengarten, Frankfurt am Main, Germany

13 Goethe-Universität Frankfurt, Frankfurt am Main, Germany 14 Medical Director Exeltis Europe, Ismaning, Germany

\section{Key words}

oral progestins, drospirenone, progestin mono-preparations, contraception, control of menstrual bleeding

\section{Schlüsselwörter}

orale Gestagene, Drospirenon, Gestagen-Monopräparate,

Kontrazeption, Blutungskontrolle

\section{received}

accepted after revision

published online
Bibliography

Geburtsh Frauenheilk 2021; 81: 1021-1030

DOI $10.1055 / a-1471-4408$

ISSN 0016-5751

(C) 2021. The Author(s).

This is an open access article published by Thieme under the terms of the Creative Commons Attribution-NonDerivative-NonCommercial-License, permitting copying and reproduction so long as the original work is given appropriate credit. Contents may not be used for commercial purposes, or adapted, remixed, transformed or built upon. (https://creativecommons.org/licenses/by-nc-nd/4.0/)

Georg Thieme Verlag KG, Rüdigerstraße 14,

70469 Stuttgart, Germany

Correspondence

Prof. Pedro-Antonio Regidor, MD PhD

Medical Director Exeltis Europe

Adalperostraße 84, 85737 Ismaning, Germany

pedro-antonio.regidor@exeltis.com

$\Theta$

Deutsche Version unter:

https://doi.org/10.1055/a-1471-4408

\section{ABSTRACT}

Hormonal contraceptives are an effective and safe method for preventing pregnancy. Progestins used in contraception are either components of combined hormonal contraceptives (tablets, patches or vaginal rings) or are used as a single active ingredient in progestin mono-preparations (the progestin-only pill (POP), implants, intrauterine systems or depot preparations). Progestins are highly effective in long-term contraception when used properly, and have a very good safety profile with very few contraindications. A new oestrogen-free ovulation inhibitor (POP) has recently been authorised in the USA and the EU. This progestin mono-preparation contains $4 \mathrm{mg}$ of drospirenone (DRSP), which has anti-gonadotropic, antimineralocorticoidic and anti-androgenic properties. The hormone administration regimen of 24 days followed by a 4-day hormone-free period was chosen to improve bleeding control 
and to maintain oestradiol concentrations at early follicularphase levels, preventing oestrogen deficiency. Clinical trials have demonstrated a high contraceptive effectiveness, a very low risk of cardiovascular side effects and a favourable menstrual bleeding pattern. Due to the long half-life of DRSP (30-34 hours), the effectiveness of the preparation is maintained even if a woman forgets to take a pill on a single occasion. Studies involving deliberate 24-hour delays in taking a pill have demonstrated that ovulation inhibition is maintained if a single pill is missed. Following a summary of the current status of oestrogen-free contraception, this review article will describe the clinical development programme of the $4 \mathrm{mg}$ DRSP mono-preparation and the resulting data on the effectiveness and safety of this new oestrogen-free oral hormonal contraceptive.

\section{ZUSAMMENFASSUNG}

Hormonelle Kontrazeptiva stellen eine effektive und sichere Methode der Schwangerschaftsverhütung dar. Die Gestagene, die in der Kontrazeption verwendet werden, sind entweder Bestandteil kombinierter hormoneller Kontrazeptiva (Tabletten, Pflaster oder Vaginalringe) oder werden als einzelner Wirkstoff in Gestagen-Monopräparaten (Tabletten [im englischen Sprachgebrauch „POP“ = Progestin-only-Pill], Implantate, Intrauterinsysteme oder Depotpräparate) eingesetzt. Gestagene sind in der Langzeitverhütung bei adäquater An- wendung höchst effektiv und haben ein sehr gutes Sicherheitsprofil mit nur wenigen Kontraindikationen. Kürzlich wurde ein neuer östrogenfreier Ovulationshemmer (POP) in den USA und der EU zugelassen. Das Gestagen-Monopräparat enthält $4 \mathrm{mg}$ Drospirenon (DRSP), welches antigonadotrope, antimineralokortikoide und antiandrogene Eigenschaften aufweist. Das Einnahmeschema mit 24-tägiger Hormonanwendung, gefolgt von einem 4-tägigen hormonfreien Intervall, wurde gewählt, um die Blutungskontrolle zu verbessern, die Estradiolspiegel auf dem Niveau der frühen Follikelphase zu halten und somit einen Estrogenmangel zu vermeiden. Klinische Studien belegten die hohe kontrazeptive Wirksamkeit, ein sehr geringes Risiko für kardiovaskuläre Nebenwirkungen und ein günstiges Blutungsmuster. Aufgrund der langen Halbwertszeit von DRSP (30-34 Stunden), bleibt die Wirksamkeit des Präparats selbst bei einmaligem Vergessen der Pilleneinnahme erhalten. Die Aufrechterhaltung der Ovulationshemmung bei möglichem Vergessen einer Pilleneinnahme wurde in Studien mit geplanten 24-stündigen Einnahmeverzögerungen gezeigt. Nach einem Überblick über den aktuellen Stand der estrogenfreien Kontrazeption beschreibt die vorliegende Arbeit das klinische Entwicklungsprogramm des 4-mg-DRSPMonopräparats und die daraus resultierenden Daten zur Wirksamkeit und Sicherheit dieses neuen estrogenfreien oralen hormonellen Kontrazeptivums.

\section{Introduction}

\section{Use of oral progestin mono-preparations (progestin-only pills)}

Of all the factors influencing a woman's choice of contraceptive method - its effectiveness, personal preferences of the patient, potential additional benefits [1] - most important is the associated risk profile. For several years, the WHO has published a comprehensive set of guidelines on the use of hormonal contraceptive methods, providing advice for and against the use of certain (hormonal) contraceptive methods in a variety of medical scenarios (pre-existing conditions, concomitant medications, etc.) [2]. Its recommendations are grouped into four categories. Methods that on the grounds of a specific medical history fall into category 1 can be recommended without restriction. In contrast, category 4 methods are associated with a high risk to health and should be avoided. Category 2 and 3 methods should only be administered after a rigorous risk-benefit assessment, and while the benefits of category 2 contraceptives generally outweigh the risks, category 3 methods should only be used if no alternative is available [2]. The advantages of the WHO guidelines are evident. They provide very concrete treatment recommendations, ensure a measure of safety from a legal standpoint, and it is relatively easy to employ and document them in consultations. However, even in a set of guidelines as extensive as those published by the WHO it is impossible to cover all specific risk scenarios.
Many potential risks of hormonal contraception can be attributed to the oestrogen component $[3,4]$, which is why in various scenarios the WHO guidelines classify combined hormonal contraceptives (CHCs) under category 4 and are therefore contraindicated ( $\vee$ Table 1 ). The most important factor in this respect is the increase in the risk of thrombosis due to exogenously administered oestrogens (especially ethinyloestradiol, a constituent of most combined contraceptives), which has been observed for all forms of administration (tablet, patch or vaginal ring) [4-6]. Progestins in $\mathrm{CHCs}$ modulate the thromboembolic risk, resulting in estimated incidences of a venous thromboembolic event (VTE) of 5-7 per 10000 women per year of use for levonorgestrel-containing and norgestimate/norethisterone-containing $\mathrm{CHCs}$ and 912 , for gestodene/desogestrel/drospirenone-containing CHCs [6]. On the other hand, the current state of knowledge suggests that progestin mono-preparations do not increase VTE risk, with the exception of depot injections containing high doses of medroxprogesterone acetate [5].

Over time, $\mathrm{CHCs}$ have been developed with very low doses of ethinyloestradiol $(E E)(10-30 \mu \mathrm{g})$ or oestradiol $\left(E_{2}\right)$, or ovulation inhibitors with no oestrogen component at all [7].

A recent review by Khialani et al. [3] clearly found that the EE component in $\mathrm{CHCs}$ is responsible for the increase in cardiovascular risk and in a dose-dependent manner.

Oral progestin mono-preparations were originally intended for use during breastfeeding, as the highest risk of VTE occurs during the postpartum period and oestrogens can reduce milk production, depending on dosage. Termed the "mini-pill", they contain 
- Table 1 Extract from the WHO guidelines on the use of combined hormonal contraceptives (CHCS) and POPs in specific medical scenarios. Complete overview: see [2].

\begin{tabular}{|c|c|c|c|c|}
\hline Risk factor & & $\mathrm{CHC}$ & Patch/ring & POP \\
\hline \multirow[t]{4}{*}{ VTE/pulmonary embolism } & Medical history & 4 & 4 & 2 \\
\hline & Acute & 4 & 4 & 2 \\
\hline & Anticoagulation discontinued & 4 & 4 & 2 \\
\hline & Fam. history (grade 1) & 2 & 2 & 1 \\
\hline \multirow[t]{3}{*}{ VTE and operations } & Major surgery, prolonged immobilisation & 4 & 4 & 2 \\
\hline & Without prolonged immobilisation & 2 & 2 & 1 \\
\hline & Minor surgery, without immobilisation & 1 & 1 & 1 \\
\hline Thrombogenic mutation & Factor $\mathrm{V}$ Leiden and prothrombin mutations, for instance & 4 & 4 & 2 \\
\hline Ischaemic heart disease & Acute or in history & 4 & 4 & $2(I) / 3(C)$ \\
\hline Stroke & & 4 & 4 & $2(I) / 3(C)$ \\
\hline Multiple risk factors for ATE & Including age, smoking, diabetes, hypertension, dyslipidaemia & $3 / 4$ & $3 / 4$ & 2 \\
\hline \multirow[t]{3}{*}{ Age } & Menarche up to $<18$ years old & NDA & NDA & 1 \\
\hline & $<40$ years old & 1 & 1 & 1 \\
\hline & $>40$ years old & 2 & 2 & 1 \\
\hline \multirow[t]{2}{*}{ Smoking } & $<35$ years old & 2 & 2 & 1 \\
\hline & $\begin{array}{l}>35 \text { years old } \\
\text { - < } 15 \text { cigarettes } \\
\text { = > } 15 \text { cigarettes }\end{array}$ & $\begin{array}{l}3 \\
4\end{array}$ & $\begin{array}{l}3 \\
4\end{array}$ & $\begin{array}{l}1 \\
1\end{array}$ \\
\hline \multirow{8}{*}{$\begin{array}{l}\text { Hypertension (without } \\
\text { other risk factors) }\end{array}$} & After hypertension (in the absence of measured values) & 3 & 3 & 2 \\
\hline & Well-controlled hypertension & 3 & 3 & 1 \\
\hline & $140-159 / 90-99$ mmHg & 3 & 3 & 1 \\
\hline & $\geq 160 / \geq 100 \mathrm{mmHg}$ & 4 & 4 & 2 \\
\hline & Vascular disorder & 4 & 4 & 2 \\
\hline & Non-vascular disorder & 2 & 2 & 2 \\
\hline & Neuropathy/retinopathy/nephropathy & $3 / 4$ & $3 / 4$ & 2 \\
\hline & Other vascular disorders or diabetes for $>20$ years & $3 / 4$ & $3 / 4$ & 2 \\
\hline
\end{tabular}

VTE: venous thromboembolic event, ATE: arterial thromboembolic event, I: initiation, C: continuation

very low doses and only inhibit ovulation in about $50 \%$ of cycles. The contraceptive action is mainly caused by an increase in cervical mucus viscosity, disruption of tubal motility and premature secretory transformation of the endometrium. The Pearl Index (PI) for these preparations is significantly worse than that for $\mathrm{CHCs}$. The introduction of the higher-dose, and thus much more reliable, ovulation-inhibiting progestin mono-preparation containing desogestrel has made the concept of oestrogen-free contraception attractive to a much larger population of women.

\section{Progestin structure and receptor interaction}

Depending on their structure, progestins interact differently with the body's various steroid receptors. Steroid receptors are located both within the cell body and on the membrane of target cells and influence protein biosynthesis at the level of DNA transcription.

The following receptors bind progestins:

- Progesterone receptors (PRs). PR has two isoforms: PR-A and PR-B. PR-A mainly acts by repressing the transcriptional activity of PR-B as well as that of oestrogen, androgen, glucocorticoid and mineralocorticoid receptors. PR-B, in contrast, has an activating effect on transcription.
- Androgen receptors. Activation of androgen receptors mediates androgenic effects, for example those that result in hair growth and sebaceous gland activity. Some progestins bind to these receptors and can either block or activate them.

- Oestrogen receptors. These receptors exert an effect in many different tissues; in the context of use of contraceptives, their most important effect is to induce endometrial proliferation.

- Glucocorticoid receptors. Glucocorticoid receptors have been linked with activation of the coagulation system.

- Mineralocorticoid receptors. These receptors modulate sodium retention.

Progestins are grouped on the basis of the differing strength with which they activate these receptors: androgenic, anti-androgenic, slightly anti-androgenic, neutral or anti-mineralocorticoidic partial effects. Of the progestins used in treatment, only DRSP and (synthetic) progesterone have anti-mineralocorticoid effects, whereas levonorgestrel, norgestimate and desogestrel have androgenic effects, and DRSP, dienogest, cyproterone acetate (CPA) and chlormadinone acetate (CMA) have anti-androgenic effects [8]. 
The anti-androgenic effect, which has been demonstrated in cell cultures and animal models [9], is not in CHC solely due to the progestin component, but also to the fact that the EE-induced increase in sex hormone binding globulin (SHBG) reduces the level of free testosterone in the body.

\section{Classification of progestins based on their market introduction}

It has become common practice to employ the following "historical" classification scheme. This distinguishes between first, second, third and fourth $\mathrm{CHC}$ generations.

- First generation: norethynodrel, norethisterone acetate

- Second generation: levonorgestrel

- Third generation: gestodene, desogestrel, norgestimate

- Fourth generation: DRSP

Cyproterone acetate (CPA) and chlormadinone acetate (CMA) were never incorporated into this categorisation, because oral contraceptives containing CPA were originally classified as drugs to treat hyperandrogenaemia in women requiring contraception. CMA has only been introduced in a small number of European countries and is not available internationally. The same applies to dienogest, which was developed in Germany [9].

\section{Advantages of progestin mono-preparations}

Progestin mono-preparations can be recommended in many scenarios where combined contraceptives fall under WHO category 3 or 4.

The German S3 guideline explicitly states that progestin mono-preparations do not significantly increase VTE risk. Only depot medroxyprogesterone acetate (DPMA), which is injected every three months, has been found in one study to increase VTE risk (3.6-fold).

Absolute contraindications (category 4) for the use of CHCs include, acute VTE, a history of VTEs, surgery with prolonged immobilisation or the presence of thrombogenic mutations, such as factor $\mathrm{V}$ Leiden. In contrast, POPs fall into category 2 and can generally be recommended after weighing up their risk-benefit ratio ( $\triangleright$ Table 1) [2]. Obesity (BMI > $\left.30 \mathrm{~kg} / \mathrm{m}^{2}\right)$ is also classified as a potential risk factor for $\mathrm{CHC}$ use, and only falls under category 2 if no further risk factors exist. However, if obesity is additionally associated with hypertension, hyperlipidaemia or diabetes mellitus, oestrogen-free contraceptive methods should be preferred [10]. Even moderate hypertension (140-159/90-99 mmHg) or well-controlled hypertension can be affected by CHCs, making it necessary to carefully consider and monitor their use (category 3 ) or contraindicate their use in the presence of further risk factors [2]. Severe hypertension ( $\geq 160 / \geq 100 \mathrm{mmHg}$ ), as well as vascular disorders in general, are contraindications for oestrogen-containing contraceptives according to the WHO, while POPs can generally be recommended in all these scenarios (category 1 or 2). Diabetes mellitus does not, in itself, restrict CHC use (category 2). However, as soon as it is additionally accompanied by vascular damage, neuropathies or retinopathies, CHCs should only be employed in exceptional cases or are contraindicated, while POPs are considered to be unproblematic (category 2). Smoking is another important VTE risk factor that becomes more pronounced with increasing age and
- Table 2 VTE risk of combined hormonal contraceptives as per the EMA/BfArM [6, 7].

\begin{tabular}{|l|l|l|}
\hline $\begin{array}{l}\text { Progestins in CHC } \\
\text { combined with } \\
\text { ethinyloestradiol }\end{array}$ & $\begin{array}{l}\text { Relative risk vs. } \\
\text { levonorgestrel }\end{array}$ & $\begin{array}{l}\text { Estimated inci- } \\
\text { dence (per 10000 } \\
\text { women and } \\
\text { year of usage) }\end{array}$ \\
\hline $\begin{array}{l}\text { Non-pregnant non-user } \\
\text { Levonorgestrel }\end{array}$ & - & 2 \\
\hline $\begin{array}{l}\text { Norgestimate/ } \\
\text { norethisterone }\end{array}$ & 1.0 & $5-7$ \\
\hline Dienogest & 1.6 & $5-7$ \\
\hline $\begin{array}{l}\text { Gestodene/deso- } \\
\text { gestrel/drospirenone }\end{array}$ & $1.5-2.0$ & $8-11$ \\
\hline $\begin{array}{l}\text { Etonogestrel/ } \\
\text { norelgestromin }\end{array}$ & $1.0-2.0$ & $9-12$ \\
\hline $\begin{array}{l}\text { Chlormadinone/nome- } \\
\text { gestrol acetate (E2) }\end{array}$ & Still to be verified & Still to be verified \\
\hline
\end{tabular}

the number of cigarettes smoked. Accordingly, $\mathrm{CHC}$ use in women younger than 35 years falls under category 2, while in patients older than 35 , CHCs should only be used in exceptional cases and after careful consideration of other risks (category 3 ) and are contraindicated if more than 15 cigarettes are consumed per day. However, according to the WHO [2], POPs can be used by all women smokers regardless of age or amount of nicotine consumed.

The German S3 guidelines on contraception adopt the same approach as the $\mathrm{WHO}$, likewise the recommendations and risk assessments of the European Medicines Agency (EMA). In the latest version of these (implemented by the BfArM in December 2018), the EMA presents the most recent risk assessment of the occurrence of venous thromboembolism. A new finding is that combination preparations with dienogest also significantly increase the risk of such VTEs ( $\triangleright$ Table 2 ).

Based on these examples alone, it is clear that CHCs are not an option, or only a very limited option, for a subset of female patients. Consequently, oestrogen-free hormonal contraception is highly important. In addition to oral progestin mono-preparations (the progestin-only pill [POP]), long-term methods based on a levonorgestrel intrauterine system (LNG-IUS), sub-dermal implants (etonogestrel) or injected depot medroxyprogesterone acetate (DMPA) are available. Although the long-term options mentioned are highly effective methods of contraception [11,12], they are not equally suitable for all patient groups. DMPA, for instance, not only seems to have an adverse effect on thrombosis risk [13], longterm use ( $>4$ years) also leads to an increased risk of bone fracture, which is attributable to a reduction in bone mineral density [14]. Hence, this method is contraindicated in women under 18 years of age and is not recommended as a first-choice method [14]. Currently available sub-dermal implants with etonogestrel, on the other hand, have no proven adverse effect on bone density and thrombosis risk, but appear to have an unfavourable effect on bleeding patterns [15]. LNG-IUS contraception is highly effective, does not prevent ovulation, has a favourable side-effect profile and is usually well accepted [16]. Problematic, however, is the fact that intrauterine implantation is rejected by some women and is expensive. 
In addition, there is increasing evidence of a potential link between LNG IUS and adverse psychiatric side effects such as panic attacks [17].

Oral progestin mono-preparations are suitable for both shortterm and longer-term hormonal contraception. Preparations that do not inhibit ovulation and whose contraceptive effectiveness is based primarily on thickening of the cervical mucus and desynchronisation of endometrial development have the disadvantage that they rely on a very narrow time window ( $3 \mathrm{~h}$ ), and their contraceptive effectiveness, consequently, is highly dependent on user compliance. Accordingly, the Pearl Index value for the $30 \mathrm{\mu g}$ levonorgestrel-only preparation is 4.14 [18].

In contrast, continuous oral POP with $75 \mu \mathrm{g}$ desogestrel reliably suppresses ovulation, and, hence, requires less strict dosing regimens ( $12 \mathrm{~h}$ time window for a missed pill) and a Pearl Index comparable to that of standard CHCs $[12,19]$.

Compared to $\mathrm{CHC}$, progestin mono-preparations do not increase the risk of stroke, myocardial infarction and thrombosis $[4,14,20]$ (with the exception of DMPA) and are also recommended for breastfeeding women. In addition, oestrogen-related side effects such as nausea, mastodynia and oedema do not occur. In addition, their continuous use makes them well suited for treating cycle-related complaints such as dysmenorrhoea, premenstrual syndrome, hypermenorrhoea and menstrual migraine, which have been shown to improve in many cases $[11,19]$.

\section{Disadvantages of progestin mono-preparations}

Oestrogen-free hormonal contraception, nevertheless, has traditionally also been associated with specific drawbacks. These include bleeding disorders such as bleeding between periods, spotting or prolonged bleeding. The fragility of the superficial vessels in the endometrium plays a role in these, as do local changes in steroid response, structural changes, tissue permeability and local factors contributing to neovascularisation [21,22]. Bleeding disorders occur in up to $50 \%$ of users of the $75 \mu \mathrm{g}$ desogestrel POP [19] and are a common reason for patients to discontinue treatment [23], which is problematic as poor compliance can reduce contraceptive effectiveness.

Other frequently cited side effects of oestrogen-free contraceptive methods include androgenisation symptoms such as acne. The oestrogen component of combined contraceptives induces SHBG formation in the liver, resulting in increased binding of testosterone and dihydrotestosterone, which can then no longer bind to and activate androgen receptors. Progestins with partial anti-androgenic effects reinforce the anti-androgenic effect of combination preparations. None of the progestin mono-preparations approved to date for contraception use progestins with an anti-androgenic partial effect, and so none of the mentioned anti-androgenic effects are likely to come into play.

The use of hormonal contraceptives can result in mood swings, and even oestrogen-free hormonal contraceptives seem to increase the risk of antidepressant use [24]. However, the extent to which various progestins result in psychobehavioral side effects in various ways or to varying degrees still needs to be investigated [25].

The issue of whether contraceptive use in adolescents is safe is frequently discussed. In particular, in the case of oestrogen-free ovulation inhibitors the concern is that suppressing endogenous oestradiol synthesis without an exogenous supply of oestrogen could impair attainment of adequate bone density. Long-term use of DMPA does indeed lead to an increased lifetime risk of fracture. In contrast, LNG-IUS, the etonogestrel implant and the $75 \mu \mathrm{g}$ desogestrel POP are not expected to negatively impact bone density, as oestradiol levels during use of these preparations are within ranges considered safe for bone formation [25]. However, no explicit studies on safety and efficacy in adolescents have been conducted for any of the preparations mentioned.

In the search for new contraceptives, the oestrogen-free $75 \mu \mathrm{g}$ desogestrel pill has proven to be a safe and effective alternative [18]. However, its 12-hour window to remedy a missed pill still gives it a narrower window than preparations containing $20 \mu \mathrm{g}$ $\mathrm{EE} / 3 \mathrm{mg}$ DRSP [26] and $1.5 \mathrm{mg} \mathrm{E}_{2} / 2.5 \mathrm{mg}$ nomegestrol acetate [27], which have a 24-hour window to remedy a missed pill. Also, due to the bleeding irregularities associated with $75 \mu \mathrm{g}$ desogestrel, the rate of premature discontinuation of treatment is higher [20]. - Table 3 lists the oral progestin mono-preparations currently available on the market and their partial effects.

\section{Recent development of the $4 \mathrm{mg}$ drospirenone (DRSP)-only pill}

The DRSP-only pill contains $4 \mathrm{mg}$ of non-micronised DRSP (and is hence a progestin mono-preparation) and is administered in a 24/ 4 regimen. This was selected to improve the bleeding profile and maintain oestradiol levels at a level similar to those during the early follicular phase of the natural menstrual cycle. Furthermore, since DRSP has a half-life of 30-34 hours, effectiveness should be maintained even if a pill is missed. Clinical development was based on the medical necessity to develop an oestrogen-free pill with the following characteristics:

- A contraceptive effectiveness comparable to that of $\mathrm{CHC}$ (= doubled ovulation-inhibiting dosage!).

- An improvement in bleeding pattern compared to other oestrogen-free preparations due to a cyclic regimen of 24 consecutive DRSP tablets followed by 4 placebo tablets. This induces planned withdrawal bleeding to reduce bleeding between periods and/or spotting.

- A wide window of effectiveness. The new $4 \mathrm{mg}$ DRSP preparation has a 24-hour window of effectiveness in which a missed pill can be remedied.

- A reduced risk of osteoporosis. Maintaining early follicular oestradiol levels should result in normal bone metabolism without increasing the risk of osteoporosis or fracture.

- An anti-androgenic and anti-mineralocorticoidic partial effect

- Treatment adherence and acceptance of this treatment regimen

\section{Effectiveness}

\section{Preclinical data}

Pharmacological properties

DRSP is a progestin (a synthetic progestogen) chemical analogue of spironolactone. In addition to its anti-oestrogenic and anti-gonadotropic effects, it also has anti-androgenic and anti-mineralocorticoidic partial effects ( $\bullet$ Table 3 ) [28]. 
- Table 3 Partial effects of selected progestins that are components of progestin mono-preparations (see also [8]).

\begin{tabular}{|l|l|l|l|l|l|l|l|l|}
\hline $\begin{array}{l}\text { Progestin mono- } \\
\text { preparations }\end{array}$ & $\begin{array}{l}\text { Pro- } \\
\text { gestogenic }\end{array}$ & $\begin{array}{l}\text { Anti- } \\
\text { gonado- } \\
\text { tropic }\end{array}$ & $\begin{array}{l}\text { Anti- } \\
\text { oestro- } \\
\text { genic }\end{array}$ & $\begin{array}{l}\text { Oestro- } \\
\text { genic }\end{array}$ & $\begin{array}{l}\text { Andro- } \\
\text { genic }\end{array}$ & $\begin{array}{l}\text { Anti-an- } \\
\text { drogenic }\end{array}$ & $\begin{array}{l}\text { Gluco- } \\
\text { corticoidic }\end{array}$ & $\begin{array}{l}\text { Anti- } \\
\text { mineralo- } \\
\text { corticoidic }\end{array}$ \\
\hline Norethisterone & + & + & + & + & + & - & - & - \\
\hline $\begin{array}{l}\text { Pro- } \\
\text { coagula- } \\
\text { tory }\end{array}$ & + \\
\hline Levonorgestrel & + & + & + & - & + & - & - & - \\
\hline Desogestrel & + & + & + & - & + & - & - & - \\
\hline Drospirenone & + & + & + & - & - & + & - & - \\
\hline
\end{tabular}

Pharmacokinetics

Results from initial preclinical pharmacokinetic studies revealed that $4 \mathrm{mg}$ of non-micronised DRSP would provide an area under the curve equivalent to that of $3 \mathrm{mg}$ of commercially available micronised DRSP $/ 20 \mu \mathrm{g}$ EE. Therefore, a dose of $4 \mathrm{mg}$ per tablet was chosen for this progestin mono-preparation. This prediction was based on the knowledge that DRSP's pharmacokinetics are linear in nature [30,31].

Systemic exposure to DRSP was lower (77\% relative bioavailability) after taking the $4 \mathrm{mg}$ tablet of non-micronised DRSP than after taking a combination pill containing $3 \mathrm{mg}$ micronised DRSP and $20 \mu \mathrm{g}$ EE [32]. The higher DRSP exposure after taking the combined pill is presumably due to the superior absorption of micronised versus non-micronised DRSP. In addition, an inhibitory effect of EE on sulphotransferase 1A1 has been discussed. This enzyme is involved in the metabolism of DRSP and catalyses the formation of the metabolite 4,5-dihydrodrospirenone-3-sulphate [32, 33].

\section{Phase II trials}

DRSP's anti-gonadotropic effect results in inhibition of ovulation

The anti-gonadotropic effect of $4 \mathrm{mg}$ DRSP has been demonstrated in phase II trials. Inhibition of ovulation (defined as occurring when serum progestogen levels fall below $16 \mathrm{nmol} / \mathrm{l}$ ) was demonstrated in healthy young women $(n=20)$ over two administration cycles. This finding was confirmed in another study that investigated the ovulation inhibition of $4 \mathrm{mg}$ DRSP taken in a 24/4 regimen compared with continuous administration of $75 \mu \mathrm{g}$ desogestrel over two administration cycles in healthy women aged $18-35$ years. In this study, ovulation was suppressed just as effectively by the $4 \mathrm{mg}$ DRSP regimen as by the $75 \mu \mathrm{g}$ desogestrel regimen [34].

\section{Inhibition of ovulation in spite of delayed administration}

The ability of $4 \mathrm{mg}$ DRSP to maintain ovulation inhibition even when a pill is delayed was investigated in an open randomised trial in which young healthy women $(n=127)$ delayed taking the pill for $24 \mathrm{~h}$ on pre-determined cycle days [35]. This trial showed that the ovulation rate with $4 \mathrm{mg}$ DRSP was much lower than with traditional POPs (30-40\%). It was comparable to, or even slightly lower than, the ovulation rate with $\mathrm{CHCs}(1.1-2.0 \%)$ and lower than the ovulation rate with $75 \mu \mathrm{g}$ desogestrel after three planned 12-hour delays (1\%) [36].

\section{Phase III trials}

\section{Effectiveness}

The contraceptive effectiveness of $4 \mathrm{mg}$ DRSP has been confirmed by phase III clinical trials, two from Europe [37,38] and one from the US [39]. A pooled analysis of the two European trials resulted in a Pearl Index of 0.73 (95\% confidence interval [CI] 0.3133 , 1.4301 ) (14329 cycles with $4 \mathrm{mg}$ DRSP) and a corrected Pearl Index (taking into account sexual activity and use of other contraceptive methods) of 0.79 (95\% Cl $0.3410,1.5562)$ [38].

The pooled analysis of a subgroup of 1251 women $\leq 35$ years of age yielded similar results: an overall Pearl Index (based on 11145 cycles) of 0.93 (95\% Cl 0.4029, 1.8387) and a corrected Pearl Index (based on 10173 cycles) of 1.02 (95\% Cl 0.4414 , 2.0144) [38]. The findings of both studies show that the contraceptive effectiveness of $4 \mathrm{mg}$ DRSP is comparable to that of currently available CHCs ( $>$ Table 4 ). In the US study of 915 nonbreastfeeding women $\leq 35$ years of age, the Pearl Index was 2.9 $(95 \% \mathrm{Cl} 1.5,5.1)$ [38]. The rate of discontinuation in the three clinical trials $(27.8 \%$ and $19.8 \%$ in the European trials [37,38] and $65 \%$ in the US trial [39]) could potentially bias the results for the primary endpoint and the safety profile, including adverse events.

The higher rate of trial withdrawals in the USA compared to the European pivotal trials is not unusual and the fact that $86 \%$ of participants reported being satisfied with the DRSP treatment puts this finding into context. Furthermore, a minimum of 5000 cycles was required to obtain one PI value. This was clearly exceeded [38].

\section{Safety}

\section{Haemostaseological parameters}

A long-term study investigated the influence of $4 \mathrm{mg}$ DRSP on coagulation factors and potential thromboembolic risks from a haemostaseological perspective [40]. The study included 39 women who took $4 \mathrm{mg}$ DRSP for 9 cycles (24/4 regimen) and 29 subjects who took $75 \mu$ desogestrel daily over the same period. The following haemostaseological parameters were investigated: resistance to activated protein C, antithrombin III, D-dimer, C-reactive protein and coagulation factors VII and VIII [40]. The study revealed that $4 \mathrm{mg}$ DRSP had no effect on haemostaseological parameters and did not affect the balance between pro-coagulatory and anti-coagulatory factors.

\section{Thromboembolic events}

Over the period of the entire clinical development programme (>20000 cycles), no reports of VTEs in women taking 4 mg DRSP 
- Table 4 Contraceptive effectiveness of the $4 \mathrm{mg}$ DRSP mono-preparation: Pearl Index data from the European pivotal trials.

\begin{tabular}{|c|c|c|c|c|}
\hline \multirow[t]{2}{*}{ Pearl Index } & \multirow{2}{*}{$\begin{array}{l}\text { Archer et al. [37] } \\
\text { Drospirenone } \\
4 \text { mg }(n=713)\end{array}$} & \multicolumn{2}{|c|}{ Palacios et al. [38] } & \multirow{2}{*}{$\begin{array}{l}\text { Pooled analysis } \\
\text { Drospirenone } \\
4 \mathrm{mg}(\mathrm{n}=1571)\end{array}$} \\
\hline & & $\begin{array}{l}\text { Drospirenone } \\
4 \mathrm{mg}(\mathrm{n}=858)\end{array}$ & $\begin{array}{l}\text { Desogestrel } \\
75 \mu g(n=332)\end{array}$ & \\
\hline \multicolumn{5}{|l|}{ Total } \\
\hline Total number of treatment cycles & 7638 & 6691 & 2487 & 14329 \\
\hline Pregnancies, n (\%) & $3(0.4)$ & $5(0.6)$ & $1(0.3)$ & $8(0.5)$ \\
\hline Pearl Index overall, \% & 0.5106 & 0.9715 & 0.5227 & 0.7258 \\
\hline $95 \% \mathrm{Cl}$ (lower limit, upper limit) & $0.1053,1.4922$ & $0.3154,2.2671$ & $0.0132,2.9124$ & $0.3133,1.4301$ \\
\hline \multicolumn{5}{|c|}{ Post correction (additional contraceptive methods and sexual activity status) } \\
\hline $\begin{array}{l}\text { Total number of cycles with sexual activity } \\
\text { and without additional contraception }\end{array}$ & 7191 & 5977 & 2224 & 13168 \\
\hline Pregnancies, n (\%) & $3(0.4)$ & $5(0.6)$ & $1(0.3)$ & $8(0.5)$ \\
\hline Corrected Pearl Index, \% & 0.5423 & 1.0875 & 0.5845 & 0.7898 \\
\hline 95\% Cl (lower limit, upper limit) & $0.1118,1.5850$ & $0.3531,2.5379$ & $0.0148,3.2568$ & $0.3410,1.5562$ \\
\hline \multicolumn{5}{|l|}{ Method failures } \\
\hline Total number of perfect medication cycles & 6101 & 4641 & 1816 & 10742 \\
\hline Pregnancies, n (\%) & $3(0.4)$ & $5(0.6)$ & $1(0.3)$ & $8(0.5)$ \\
\hline Pearl Index method failures, \% & 0.6392 & 1.4006 & 0.7159 & 0.9682 \\
\hline 95\% Cl (lower limit, upper limit) & $0.1318,1.8681$ & $0.4548,3.2684$ & $0.0181,3.9885$ & $0.4180,1.9077$ \\
\hline \multicolumn{5}{|l|}{ Overall pregnancy rate } \\
\hline$\%$ & 0.50 & 0.70 & 0.34 & 0.73 \\
\hline $95 \% \mathrm{Cl}$ (lower limit, upper limit) & $0.00,1.07$ & $0.09,1.31$ & $0.00,1.01$ & $0.17,1.27$ \\
\hline
\end{tabular}

were reported [41]. The documented risk factors included a family history of thromboembolic events, evidence of a predisposition to vascular or metabolic disease, smoking if over 35 years of age, not smoking and over 40 years of age, and a body mass index (BMI) of $\geq 30 \mathrm{~kg} / \mathrm{m}^{2}$. In the US study, at least 367 participants (36.5\%) had a VTE risk factor [39], while in the European studies $139(16.2 \%)$ and 104 (14.6\%) of participants, respectively, had a VTE risk factor $[37,38]$.

These observations are consistent with the fact that $4 \mathrm{mg}$ DRSP was neutral with regard to the haemostaseological parameters examined in the above-mentioned long-term study. Future epidemiological studies will be needed to corroborate the clinical data on cardiovascular safety [41].

\section{Effect on mild hypertension}

Previous studies have shown that 6-month use of a drospirenone/ oestrogen combination was associated with a modest decrease in systolic blood pressure (SBP) and diastolic blood pressure (DBP) compared with a levonorgestrel/oestrogen combination [42,43]. This minor effect on blood pressure was also demonstrated in a study that compared the influence of a contraceptive containing $3 \mathrm{mg}$ DRSP and EE with a preparation containing $150 \mu \mathrm{g}$ desogestrel and EE [43]. The observed effect is most likely attributable to the anti-mineralocorticoidic effect of DRSP.

The two European pivotal trials also investigated the effect of $4 \mathrm{mg}$ DRSP on blood pressure. The first study demonstrated a median decrease of $8 \mathrm{mmHg}$ (SBP) and $5 \mathrm{mmHg}$ (DBP) in participants with a baseline SBP of $\geq 130 \mathrm{mHg}$ and a baseline DBP of $\geq 85 \mathrm{mmHg}(\mathrm{n}=137)[36,37]$. In participants with a baseline SBP of $<130 \mathrm{mmHg}$ and a baseline DBP of $<85 \mathrm{mmHg}(\mathrm{n}=548)$, the absolute median change was $0 \mathrm{mmHg}$ for both SBP and DBP [41].

\section{Oestradiol levels and bones}

A study of 64 volunteers [26] revealed that the $E_{2}$ level on day 24 of the second administration cycle was just below $51 \mathrm{pg} / \mathrm{ml}$ (187 pmol/l), higher than the levels on day 3 of the first cycle, which can be considered to be baseline levels. Thus, 24 days of treatment with $4 \mathrm{mg}$ DRSP did not reduce $E_{2}$ levels below the baseline levels of day 3 . The difference in $E_{2}$ levels compared to the control group ( $75 \mu \mathrm{g}$ desogestrel) was not statistically significant. Under the recommended regimen (24/4), endogenous $E_{2}$ production can occur in the ovaries, as the 4-day break should be sufficient to increase FSH levels. This was confirmed with the values from day 3 of the second administration cycle, which were higher than the values on day 27 of the first administration cycle. The new dosing regimen (24/4 regimen of $4 \mathrm{mg}$ DRSP compared to a 28-day regimen of $75 \mu \mathrm{g}$ desogestrel) resulted in higher $E_{2}$ levels at the end of administration cycle 2 than those on day 3 of the first administration cycle [26].

During the $4 \mathrm{mg}$ DRSP 24/4 regimen, mean $\mathrm{E}_{2}$ levels do not fall below $30 \mathrm{pg} / \mathrm{ml}$ (110.1 pmol/l) [25]. This value is considered a potential limit for the onset of osteoclast activity in bone, as demonstrated in the study by Doran et al. [44].

\section{Changes in body weight}

No significant changes in mean body weight occurred among users of $4 \mathrm{mg}$ DRSP during the various short and long-term studies $[36-38,40]$. This confirms data from the literature indicating 
- Table 5 Median number of planned and unplanned bleeding or spotting days and premature study withdrawals associated with AUB (abnormal uterine bleeding) in specified reference periods.

\begin{tabular}{|c|c|c|c|}
\hline \multirow[t]{2}{*}{ Variable } & \multirow{2}{*}{$\begin{array}{l}\text { Archer et al. } \\
\text { [37] } \\
\text { Drospirenone } \\
4 \text { mg }(n=713)\end{array}$} & \multicolumn{2}{|c|}{ Palacios et al. [[38.39]] } \\
\hline & & $\begin{array}{l}\text { Drospirenone } \\
4 \mathrm{mg}(\mathrm{n}=858)\end{array}$ & $\begin{array}{l}\text { Desogestrel } \\
75 \mu \mathrm{g} \\
(\mathrm{n}=332)\end{array}$ \\
\hline \multicolumn{4}{|c|}{ Total bleeding and spotting days } \\
\hline Cycles 2-4 & 11 & $10^{*}$ & 12 \\
\hline Cycles 5-7 & 8 & 6 & 7 \\
\hline Cycles 8-10/7-9a & 6 & 6 & 7 \\
\hline Cycles 11-13 & 5 & & \\
\hline \multicolumn{4}{|c|}{ Unplanned bleeding and spotting days } \\
\hline Cycles 2-4 & 6 & $5^{* *}$ & 12 \\
\hline Cycles 5-7 & 5 & $4^{*}$ & 7 \\
\hline Cycles 8-10/7-9a & 3 & $4^{*}$ & 7 \\
\hline Cycles 11-13 & 3 & & \\
\hline $\begin{array}{l}\text { Premature } \\
\text { withdrawal from } \\
\text { the trial due to } \\
\text { bleeding disorders }\end{array}$ & $30(4.2)$ & $28(3.3)$ & $22(6.6)$ \\
\hline \multicolumn{4}{|c|}{ Data are shown as n (\%) } \\
\hline \multicolumn{4}{|c|}{ a $8-10$ for study $301,7-9$ for study 302} \\
\hline \multicolumn{4}{|c|}{${ }^{*} \mathrm{p}<0.05$ drospirenone vs. desogestrel } \\
\hline \multicolumn{4}{|c|}{${ }^{* *} \mathrm{p}<0.001$ drospirenone vs. desogestrel } \\
\hline
\end{tabular}

that use of DRSP is not associated with weight gain or significant changes in body fat percentage [44].

\section{Tolerance}

Bleeding pattern: control of bleeding profile with $4 \mathrm{mg}$ DRSP in comparison to $75 \mu \mathrm{g}$ desogestrel.

A phase III clinical trial over 9 administration cycles compared bleeding profiles of women treated with $4 \mathrm{mg}$ DRSP and women treated with $75 \mu \mathrm{g}$ desogestrel $[46,47]$. The percentage of women with bleeding and spotting decreased in the $4 \mathrm{mg}$ DRSP group from $69.2 \%$ in administration cycle 2 to $56.3 \%$ in administration cycle 9 , and in the $75 \mu \mathrm{g}$ desogestrel group from $74.05 \%$ to $45.3 \%$. The median number of bleeding and spotting days decreased from 10 days in the $4 \mathrm{mg}$ DRSP group in the first reference period (administration cycles 2-4) to 6 days in the last reference period (administration cycles 7-9), and from 12 to 7 days in the $75 \mu \mathrm{g}$ desogestrel group. Most of these days were days with spotting rather than bleeding. The differences were statistically significant.

In addition, during administration cycles 5-9, the proportion of women with prolonged bleeding ( $>10$ days) was significantly lower in the $4 \mathrm{mg}$ DRSP group than in the $75 \mu \mathrm{g}$ desogestrel group $(p<0.001)$. Premature study withdrawal due to abnormal uterine bleeding (AUB) occurred in $3.3 \%$ of DRSP and $6.6 \%$ of $75 \mu \mathrm{g}$ desogestrel users $(p<0.001)[46,47]$. In summary, the results of the clinical trials revealed that $4 \mathrm{mg}$ DRSP controlled bleeding patterns better than did $75 \mu \mathrm{g}$ desogestrel. $~$ Table 5 presents data on bleeding patterns from the trials.

\section{Endometrial safety}

Endometrial thickness was assessed in a dedicated endometrial safety study [48]. The mean maximum double endometrial thickness was $5.5 \mathrm{~mm}$, and after 13 administration cycles it was reduced by an average of $2.6 \mathrm{~mm}$. Biopsies were taken to assess changes in the endometrium. After one year of treatment with $4 \mathrm{mg}$ DRSP, not a single case of hyperplasia occurred [48].

\section{Use in Special Groups}

\section{Adolescents}

A study was designed to prospectively assess the safety and tolerability of $4 \mathrm{mg}$ DRSP (24/4) in 111 adolescent females aged 1217 years [48]. The study consisted of six 28-day administration cycles and a further optional extension phase of 7 administration cycles. The number of participants reporting dysmenorrhoea decreased from 47 (46.1\%) before screening to $14(29.8 \%)$ after administration cycle 6 , and to $8(17 \%)$ after administration cycle 13 . At the same time, the percentage of women who used painkillers to treat dysmenorrhoea decreased. Only five participants $(4.9 \%)$ withdrew prematurely from the study due to irregular bleeding and one $(1 \%)$ due to amenorrhoea. No treatment-related serious adverse events and no pregnancies occurred. At the conclusion of the study, $82.4 \%$ of the participants rated the tolerability of $4 \mathrm{mg}$ DRSP as excellent or good [49].

\section{Overweight and obese women}

Obesity leads to physiological changes, such as increased cardiac output or changes in liver enzyme function, compared to individuals of normal weight. Some liver changes have the potential to alter the absorption, distribution, metabolism and elimination of drugs, reducing their efficacy [50].

The contraceptive effectiveness of DRSP in overweight and obese women has been confirmed in a pooled analysis of European studies from the clinical development programme of the $4 \mathrm{mg}$ DRSP preparation [37,38]. Four reported pregnancies $(\mathrm{PI}=1.89)$ occurred in women with a BMI of $25-30 \mathrm{~kg} / \mathrm{m}^{2}$ $(n=301)$, while no pregnancies occurred in participants with a $\mathrm{BMI} \geq 30 \mathrm{~kg} / \mathrm{m}^{2}(\mathrm{n}=71)(\mathrm{PI}=0.0)$.

The clinical programme demonstrated the favourable thromboembolic safety profile of $4 \mathrm{mg}$ DRSP, also for women with VTE risk factors. Cigarette smoking in women $>35$ years of age was the most common risk factor in the European studies (10.1\% and $12 \%$, respectively) $[37,38,41]$. In the US study $[39,41]$, this incidence was $5.1 \%$. The most common risk factor in the US study was a BMI of $>30 \mathrm{~kg} / \mathrm{m}^{2}$, accounting for $35 \%$ of the participants. In the European studies, only $5.8 \%$ and $3.5 \%$, respectively, of the participants had a BMI above $30 \mathrm{~kg} / \mathrm{m}^{2}$.

The incidence of women with a family history of thromboembolic events or of women with predisposing factors for cardiovascular or metabolic disease was lower in all studies.

In conclusion, even in women with risk factors for venous thromboembolic events (VTEs), such as being over 35 years of age, tobacco use and obesity, no venous or arterial thromboembolic events occurred [40]. 


\section{Breastfeeding women}

A prospective study investigated the amount of DRSP transferred to breast milk after reaching a steady state [51]. DRSP $4 \mathrm{mg}$ per day was administered for 7 days to reach this steady-state concentration. The mean AUC (0-24 h) of DRSP in plasma $24 \mathrm{~h}$ after administration of the last dose was $635.33 \mathrm{ng} \mathrm{h} / \mathrm{ml}$. The mean $\mathrm{C}_{\max }$ was $48.64 \mathrm{ng} / \mathrm{ml}$. The mean AUC (0-24 h) of DRSP in the mother's milk $24 \mathrm{~h}$ after administration of the last dose was $134.35 \mathrm{ng} \mathrm{h} /$ $\mathrm{ml}$. The mean $\mathrm{C}_{\max }$ was $10.34 \mathrm{ng} / \mathrm{ml}$. On average, $18.13 \%$ of plasma DRSP entered breast milk and the highest concentration measured in breast milk was $17.55 \%$ of plasma DRSP. The mean total quantity of DRSP that passed into breast milk was $4478 \mathrm{ng}$ during a 24 -hour period, equivalent to $0.11 \%$ of the maternal daily dose. Hence, no effects on breastfed newborns/infants are expected with the DRSP $4 \mathrm{mg}$ preparation at the recommended dosages, as these amounts are considered to be negligible [52].

\section{Summary}

Progestins play an essential and independent role in contraception, with or without oestrogens. Although they differ in structure and effect profile, they have a multimodal mode of action in contraception. In addition to its progesteronic effect, each progestin has an inherent partial effect profile that is highly relevant in clinical use. This can influence or determine effects and possible side effects.

In view of the available data, it may be concluded that the introduction of a new oestrogen-free contraceptive containing $4 \mathrm{mg}$ of non-micronised DRSP in a 24/4-day regimen expands contraceptive options for women and represents an innovation in modern contraception for the following reasons:

- clinical trials have shown DRSP to be highly effective (Pearl Index $=0.73$ ),

- no relevant safety concerns were identified in the clinical trials (0 thromboembolic cases in more than 20000 cycles in more than 2000 women), and

- a high acceptance rate (96.5\%) among users with a low discontinuation rate due to unacceptable bleeding disorders (91 of 2593 women (3.5\%) during all phase III trials) has been documented [52].

\section{Conflict of Interest}

Pedro-Antonio Regidor is an employee of Exeltis.

\section{References}

[1] Schindler AE. Non-contraceptive benefits of oral hormonal contraceptives. Int J Endocrinol Metab 2013; 11: 41-47. doi:10.5812/ijem.4158

[2] World Health Organization. Medical eligibility criteria for contraceptive use. 5th ed. Geneva: WHO; 2015. Accessed March 08, 2021 at: https:// www.who.int/publications/i/item/9789241549158

[3] Khialani D, Rosendaal F, van Hylckama Vlieg A. Hormonal Contraceptives and the Risk of Venous Thrombosis. Semin Thromb Hemost 2020; 46: 865-871. doi:10.1055/s-0040-1715793

[4] Lidegaard $\varnothing$, Nielsen LH, Skovlund CW et al. Risk of venous thromboembolism from use of oral contraceptives containing different progesto- gens and oestrogen doses. BM] 2011; 343: d6423. doi:10.1136/bmj. d6423

[5] Lidegaard O, Nielsen LH, Skovlund CW et al. Venous thrombosis in users of non-oral hormonal contraception: follow-up study, Denmark 200110. BMJ 2012; 344: e2990. doi:10.1136/bmj.e2990

[6] Bundesinstitut für Arzneimittel und Medizinprodukte. Rote-Hand-Brief zu den kombinierten hormonalen Kontrazeptiva. Accessed December 13, 2020 at: www.bfarm.de/SharedDocs/Risikoinformationen/ Pharmakovigilanz/DE/RHB/2014/rhb-khk.html

[7] European Medicines Agency. Combined hormonal contraceptives. Accessed May 31, 2021 at: www.ema.europa.eu/en/medicines/human/ referrals/combined-hormonal-contraceptives

[8] Schindler AE, Campagnoli C, Druckmann R et al. Classification and pharmacology of progestins. Maturitas 2008; 61: 171-180. doi:10.1016/j. maturitas.2008.11.013

[9] Regidor PA, Schindler AE. Antiandrogenic and antimineralocorticoid health benefits of $\mathrm{COC}$ containing newer progestins: dienogest and drospirenone. Oncotarget 2017; 8: 83334-83342. doi:10.18632/oncotarget.19833

[10] Römer T, Göretzlehner G. Kontrazeption mit OC in 238 Problemsituationen. 3rd ed. Berlin: De Gruyter; 2017: 3-320

[11] Ahrendt HJ, Bühling KJ. Estrogen Free Contraception: progestin-only systems. J Reprod Med Endocrinol 2010; 7 (Sonderheft 1): 97-105

[12] World Health Organization; Johns Hopkins Bloomberg School of Public Health. Family Planning: A Global Handbook for Providers. 3rd ed. 2018. Accessed May 31, 2021 at: https://apps.who.int/iris/bitstream/ handle/10665/260156/9780999203705-eng.pdf?s

[13] van Hylckama Vlieg A, Helmerhorst FM, Rosendaal FR. The risk of deep venous thrombosis associated with injectable depot-medroxyprogesterone acetate contraceptives or a levonorgestrel intrauterine device. Arterioscler Thromb Vasc Biol 2010; 30: 2297-2300. doi:10.1161/ ATVBAHA.110.211482

[14] AWMF. AWMF guideline hormonal contraception 2020. Accessed July 06, 2020 at: https://www.awmf.org/leitlinien/detail/ll/015-015.html

[15] Bachmann G, Korner P. Bleeding patterns associated with non-oral hormonal contraceptives: a review of the literature. Contraception 2009; 7: 247-58. doi:10.1016/j.contraception.2008.10.012

[16] Hsia JK, Creinin MD. Intrauterine Contraception. Semin Reprod Med 2016; 34: 175-182. doi:10.1055/s-0036-1571438

[17] World Health Organization. WHO Pharmaceuticals Newsletter No. 6 2019. Licence: CC BY-NC-SA 3.0 IGO. Geneva: World Health Organization; 2019

[18] Fachinformation 28 mini $^{\circledR}$; November 2019

[19] Cerazette ${ }^{\circledR}$ Summary of product characteristics 2020. May 2020. Accessed May 31, 2021 at: https://www.medicines.org.uk/emc/product/ 1698/smpc\#gref

[20] Lidegaard Ø, Løkkegaard E, Jensen A et al. Thrombotic stroke and myocardial infarction with hormonal contraception. N Engl J Med 2012; 366: 2257-2266. doi:10.1056/NEJMoa1111840

[21] de Melo NR. Estrogen-free oral hormonal contraception: benefits of the progestin-only pill. Womens Health (Lond) 2010; 6: 721-735. doi:10.2217/whe.10.36

[22] Smith OP, Critchley HO. Progestogen only contraception and endometrial break through bleeding. Angiogenesis 2005; 8: 117-126. doi:10.1007/s10456-005-9003-z

[23] Villavicencio J, Allen RH. Unscheduled bleeding and contraceptive choice: increasing satisfaction and continuation rates. Open Access J Contracept 2016; 7: 43-52. doi:10.2147/OAJC.S85565

[24] Skovlund CW, Mørch LS, Kessing LV et al. Association of Hormonal Contraception With Depression. JAMA Psychiatry 2016; 73: 1154-1162. doi:10.1001/jamapsychiatry.2016.2387. Erratum in: JAMA Psychiatry 2017; 74: 764 
[25] Mitchell VE, Welling LLM. Not All Progestins are Created Equally: Considering Unique Progestins Individually in Psychobehavioral Research. Adaptive Human Behavior and Physiology 2020; 6: 381-412. doi:10.1007/s40750-020-00137-1

[26] Hadji P, Colli E, Regidor PA. Bone health in estrogen-free contraception. Osteoporos Int 2019; 30: 2391-2400. doi:10.1007/s00198-019-051036

[27] Jenapharm GmbH \& Co KG. Yaz. Summary of product characteristics. July 2020. Accessed May 31, 2021 at: https://db.cbg-meb.nl/mri/spc/ nlh-1269-001.pdf

[28] Theramex Ireland Limited. Zoely. Summary of product characteristics. June 2020. Accessed May 31, 2021 at: www.medicines.org.uk/emc/ product/3038/smpc

[29] Regidor PA. The clinical relevance of progestins in hormonal contraception: present status and future developments. Oncotarget 2018; 9: 34628-34638. doi:10.18632/oncotarget.26015

[30] Fuhrmann U, Krattenmacher R, Slater EP et al. The novel progestin drospirenone and its natural counterpart progesterone: biochemical profile and antiandrogenic potential. Contraception 1996; 54: 243-251. doi:10.1016/s0010-7824(96)00195-3

[31] Krattenmacher R. Drospirenone: pharmacology and pharmacokinetics of a unique progestin. Contraception 2000; 62: 29-38. doi:10.1016/ s0010-7824(00)00133-5

[32] Richter WH, Koytchev R, Kirkov V et al. Comparative pharmacokinetic estimates of drospirenone alone and in combination with ethinyl estradiol after single and repeated oral administration in healthy females. Contraception 2020; 101: 137-143. doi:10.1016/j.contraception.2019.10.005

[33] Rohn KJ, Cook IT, Leyh TS et al. Potent inhibition of human sulfotransferase $1 \mathrm{~A} 1$ by $17 \alpha$-ethinylestradiol: role of $3^{\prime}$-phosphoadenosine $5^{\prime}$-phosphosulfate binding and structural rearrangements in regulating inhibition and activity. Drug Metab Dispos 2012; 40: 1588-1595. doi:10.1124/dmd.112.045583

[34] Duijkers IJ, Heger-Mahn D, Drouin D et al. A randomised study comparing the effect on ovarian activity of a progestogen-only pill (POP) containing desogestrel and a new POP containing drospirenone in a 24/4 regimen. Eur J Contracept Reprod Health Care 2015; 20: 419-427. doi:10.3109/13625187.2015.1044082

[35] Duijkers IJM, Heger-Mahn D, Drouin D et al. Maintenance of ovulation inhibition with a new progestogen-only pill containing drospirenone after scheduled 24-h delays in pill intake. Contraception 2016; 93: 303-309. doi:10.1016/j.contraception.2015.12.007

[36] Rice CF, Killick SR, Dieben T et al. A comparison of the inhibition of ovulation achieved by desogestrel $75 \mathrm{mg}$ and levonorgestrel $30 \mathrm{mg}$ daily. Hum Reprod 1999; 14: 982-985. doi:10.1093/humrep/14.4.982

[37] Archer DF, Ahrendt HJ, Drouin D. Drospirenone-only oral contraceptive: results from a multicenter noncomparative trial of efficacy, safety and tolerability. Contraception 2015; 92: 439-444

[38] Palacios S, Colli E, Regidor PA. Multicenter, phase III trials on the contraceptive efficacy, tolerability and safety of a new drospirenone-only pill. Acta Obstet Gynecol Scand 2019; 98: 1549-1557. doi:10.1016/j.contraception.2015.07.014

[39] Kimble T, Burke AE, Barnhart KT et al. A 1-year prospective, open-label, single-arm, multicenter, phase 3 trial of the contra- ceptive efficacy and safety of the oral progestin-only pill drospirenone $4 \mathrm{mg}$, using a 24/4day regimen. Contraception 2020; 2: 100020. doi:10.1016/j. conx.2020.100020

[40] Regidor PA, Colli E, Schindler AE. Drospirenone as estrogen-free pill and hemostasis: coagulatory study results comparing a novel $4 \mathrm{mg}$ formulation in a $24+4$ cycle with desogestrel $75 \mu \mathrm{g}$ per day. Gynecol Endocrinol 2016; 32: 749-751. doi:10.3109/09513590.2016.1161743

[41] Palacios S, Colli E, Regidor PA. Efficacy and cardiovascular safety of the new estrogen-free contraceptive pill containing $4 \mathrm{mg}$ drospirenone alone in a 24/4 regime. BMC Womens Health 2020; 20: 218. doi:10.1186/s12905-020-01080-9
[42] Oelkers W, Foidart JM, Dombrovicz N et al. Effects of a new oral contraceptive containing an antimineralocorticoid progestin, drospirenone, on the renin-aldosterone system, body weight, blood pressure, glucose tolerance, and lipid metabolism. J Clin Endocrinol Metab 1995; 80: 18161821. doi:10.1210/jcem.80.6.7775629

[43] Gaspard U, Scheen A, Endrikat J et al. A randomized study over 13 cycles to assess the influence of oral contraceptives containing ethinylestradiol combined with drospirenone or desogestrel on carbohydrate metabolism. Contraception 2003; 67: 423-429. doi:10.1016/s0010-7824 (02)00537-1

[44] Doran PM, Riggs BL, Atkinson E] et al. Effects of raloxifene, a selective estrogen receptor modulator, on bone turnover markers and serum sex steroid and lipid levels in elderly men. J Bone Miner Res 2001; 16: 2118 2125. doi:10.1359/jbmr.2001.16.11.2118

[45] Foidart JM, Faustmann T. Advances in hormone replacement therapy: weight benefits of drospirenone, a 17a-spirolactone- derived progestogen. Gynecol Endocrinol 2007; 23: 692-699. doi:10.1080/ 09513590701582323

[46] Palacios S, Colli E, Regidor PA. A multicenter, double-blind, randomized trial on the bleeding profile of a drospirenone-only pill $4 \mathrm{mg}$ over nine cycles in comparison with desogestrel $0.075 \mathrm{mg}$. Arch Gynecol Obstet 2019; 300: 1805-1812. doi:10.1007/s00404-019-05340-4

[47] Palacios S, Colli E, Regidor PA. Bleeding profile of women using a drospirenone-only pill $4 \mathrm{mg}$ over nine cycles in comparison with desogestrel 0.075 mg. PLoS One 2020; 15: e0231856. doi:10.1371/journal. pone. 0231856

[48] Regidor PA, Colli E, Georgiev D et al. Safety, influence on the endometrium, sonographic changes and bleeding profile after 13 cycles with the new drospirenone only pill (DOP) for contraception. Horm Mol Biol Clin Investig 2020. doi:10.1515/hmbci-2019-0061

[49] Apter D, Colli E, Gemzell-Danielsson K et al. Multicenter, open-label trial to assess the safety and tolerability of drospirenone $4.0 \mathrm{mg}$ over 6 cycles in female adolescents, with a 7-cycle extension phase. Contraception 2020; 101: 412-419. doi:10.1016/j.contraception.2020.02.004

[50] $\mathrm{Ng} \mathrm{M}$, Fleming T, Robinson M et al. Global, regional, and national prevalence of overweight and obesity in children and adults during 19802013: a systematic analysis for the Global Burden of Disease Study 2013. Lancet 2014; 384: 766-781. doi:10.1016/S0140-6736(14)60460-8

[51] Melka D, Kask K, Colli E et al. A single-arm study to evaluate the transfer of drospirenone to breast milk after reaching steady state, following oral administration of $4 \mathrm{mg}$ drospirenone in healthy lactating female volunteers. Womens Health (Lond) 2020; 16: 1745506520957192. doi:10.1177/1745506520957192

[52] Exeltis. Slynd. 2019. Accessed at: www.drugs.com/pro/slynd.html

\section{Correction}

Oral Progestins in Hormonal Contraception: Importance and Future Perspectives of a New Progestin Only-Pill Containing $4 \mathrm{mg}$ Drospirenone

Thomas Römer, Johannes Bitzer, Christian Egarter et al. Geburtsh Frauenheilk. doi:10.1055/a-1471-4408

In the e-first version of this article the name of the coauthor was incorrect. Correct is: Katrin Schaudig. 